ments. The low number of CFU (3.6) would be considered consistent with an ultraclean operating room environment, although laminar airflow was not employed. Coagulase-negative staphylococci were the most common isolates and probably are a good marker for shed bacterial air contamination from the operating team.

\section{REFERENCES}

1. Eftekhar NS. The surgeon and clean air in the operating room. Clin Orthop 1995;95:188-194.

2. Feagin JA. Bacteriology of the operating room with the use of helmet aspiration systems. Arch Surg 1979;114:790.

3 . Howorth FH. Prevention of airborne infection during surgery. Lancet 1985;1:386-388.

4. Whyte W, Vesley D, Hodgson R. Bacterial dispersion in relation to operating room clothing. J Hyg Epidemiol Microbial Immunol 1976;76:367-378.

5. Laufman H. Air flow effects in surgery. Arch Surg 1979;114:826830.

6. Lidwell OM, Lowburg EJL, Whyte W, Blowers R, Stanley SJ, Lowe D. Effect of ultraclean air in operating rooms on deep sep- sis in the joint after total hip or knee replacement: the randomized study. Br Med J 1982;285:10-14.

7. Brady LP, Enneking WF, Franco JA. The effect of operatingroom environment on the infection rate after Charnley lowfriction total hip replacement. J Bone Joint Surg Am 1975;57A:80-83

8. Fitzgerald RH. Microbiologic environment of the conventional operating room. Arch Surg 1979;114:772-775.

9. Ritter MA, Eitzen HE, Morris LVF, Hart JB. The effect that time, touch and environment have upon bacterial contamination of instruments during surgery. Ann Surg 1976;184:642-644.

10. Ritter MA, French MLV, Hart JB. Microbiological studies in a horizontal wall-less laminar air-flow operating room during actual surgery. Clin Orthop 1973;97:16-18.

11. Ritter MA, Eitzen H, Hart J, French M. The surgeons' garb. Clin Orthop 1980;153:204-209.

12. Inman RD, Gallegos KV, Brause BD, Redecha PB, Christian CL. Clinical and microbial features of prosthetic joint infection. Am J Med 1984;77:47-53.

13. Nelson CL. Environmental bacteriology in the unidirectional (horizontal) operating room. Arch Surg 1979;114:778-782.

14. Nelson JP, Glassburg AR, Talbott RD, McElhinney JP. Clean room operating rooms. Clin Orthop 1973;96:179-187.

15. Lidwell OM. Clean air at operation and subsequent sepsis in the joint. Clin Orthop 1986;211:91-102.

\title{
APHA Challenges Glutaraldehyde Instructions
}

\section{Gina Pugliese, RN, MS Martin S. Favero, PhD Medical News Editors}

The subject of the recent changes in the instructions for using glutaraldehyde formulations for highlevel disinfection recently was discussed by the Microbial Contamination Control Committee of the Laboratory Section of the American Public Health Association (APHA). This committee has been active in areas of environmental microbiology, disinfection, and sterilization for over 30 years and is composed of individuals from academia, several federal agencies (including $\mathrm{CDC}, \mathrm{FDA}$, and $\mathrm{EPA}$ ), and from industry.

At the committee meeting held during the week of May 19, 1996, the subject of new instructions for using glutaraldehyde as a high-level disinfectant was discussed. It was noted that, in 1993, when the EPA and FDA agreed to give the FDA the jurisdiction over label claims for chemical sterilants and disinfectants used on medical devices, there was a change in the system for manufacturers making label claims, including use instructions. As a result, Cidex (Johnson \& Johnson Medical Inc, Arlington, TX), a
$2 \%$ glutaraldehyde formulation, the first such formulation approved by the FDA under the new system, contained revised label instructions for high-level disinfection that recommended immersing medical devices for $45 \mathrm{~min}$ utes at $25^{\circ} \mathrm{C}$. This new recommendation was more stringent than the current practice for high-level disinfection of semicritical devices, such as endoscopes, which includes proper cleaning to remove residual organic matter, followed by a 20 -minute immersion at $20^{\circ} \mathrm{C}$, a practice recommended by a number of professional associations, including APIC. Changing current practice, as recommended by the majority of professional associations, to meet the revised requirements of the new labeling has been the subject of much recent debate. Most environmental microbiologists and infection control practitioners are continuing with current practice, as recommended in the APIC guidelines authored by William Rutala, PhD, MPH, citing a number of scientific studies that supported the use of a 20-minute contact time at $20^{\circ} \mathrm{C}$, provided there is adequate precleaning of the device.

The consensus of the APHA's Microbial Contamination Control Committee was to follow the recom- mendations in the APIC guidelines. Some individuals expressed concern that, because the label instructions are approved by the FDA, hospitals may be at risk of being cited or penalized. In response to these concerns, representatives from the FDA and CDC who attended the meeting pointed out that the contents of labels, including use instruction, are matters that are considered only between the FDA and the manufacturer and users; that is, hospitals are not under the purview of the FDA. The final consensus among committee members was that hospitals, if they so wished, could follow the APIC guideline and its cited scientific rationale for high-level disinfection of semicritical devices (eg, endoscopes) with glutaraldehyde and that there was no justification for penalties by a federal or accreditation agency, such as the Joint Commission on Accreditation of Healthcare Organizations.

FROM: (1) Rutala WA, Weber DJ. FDA labeling requirements for disinfection of endoscopes: a counterpoint. Infect Control Hosp Epidemiol 1995;16:231-235.

(2) Rutala WA. APIC guideline for selection and use of disinfectants. Am I Infect Control 1990;18:99-117. 